\title{
Political Imaging Techniques Carried Out by Baitul Muslimin Indonesia (BAMUSI) in Increasing Public Political Support for PDI Perjuangan Medan City
}

\author{
Sutarto $^{1}$, Suwardi Lubis ${ }^{2}$, Katimin ${ }^{2}$ \\ ${ }^{I}$ Ph.D Student in State Islamic University of Medan (UINSU), Medan, Indonesia \\ ${ }^{2}$ Lecturer in State Islamic University of Medan (UINSU), Medan, Indonesia \\ wildanansori22@gmail.com
}

\begin{abstract}
BAMUSI is a new breakthrough for PDI Perjuangan to restore the negative stigmatization directed at PDI Perjuangan so far. BAMUSI is here to build a good image of PDI Perjuangan which has only been buzzing and narrating as a national and religious based party. BAMUSI will make a movement towards Islamic understanding that is rahmatan lil 'alamin bagi for the nation. Political imaging techniques carried out by BAMUSI in increasing the political support of the people of PDI Perjuangan Medan, namely to carry out social services: Social service activities carried out by BAMUSI Medan City is an accurate strategy in approaching and touching the hearts of Medan people in fostering community trust. Delivering Assistance: The political imaging technique carried out by BAMUSI Medan City in increasing community political support for PDI Perjuangan is by channeling aid.
\end{abstract}

Keywords : PDI Perjuangan; public supprot; politics; election

\section{Introduction}

The defeat of PDI Perjuangan Party of Struggle in the 2004 and 2009 elections certainly demanded that all party organs conduct internal evaluations and reviews in a comprehensive manner and then determine strategic steps for the party's glory and progress. Systematically from systematic discussions and studies and input from various parties, both from community leaders, academics and practitioners. Affirming that PDI Perjuangan is seen as a nationalist party, the religious is perceived to be less close to the political power of Islam.

That the reality of the values of the community religiosity especially Muslims, requires selling, affirming that PDI Perjuangan is a party that is friendly and close to Muslims. Public perception that views PDI Perjuangan as close to Islamic certainty, that is what evolutionarily decreases the positive image of PDI Perjuangan in the eyes of Muslims. Therefore, the relationship of Islam is needed as a strategic step to build the image of PDI Perjuangan among Muslims and implemented in motion and steps and party programs.

As one of the implenmentation of party work programs, PDI Perjuangan broadens and strengthens network relations to build party image branding. For this reason, PDI Perjungan forms a Community Organization as a Party Wing, namely; Relawan Perjuangan Demokrasi (Repdem), Banteng Muda Indonesia (BMI), Taruna Merah Putih (TMP) and Baitul Muslimin Indonesia (BAMUSI).

This research will focus on work and activities carried out by BAMUSI in communicating with the community as an effort to improve the image for political support for PDI Perjuangan Medan City. The selection of BAMUSI as an object of study is based on the Indonesian political constellation the role of religion becomes important when faced with the reality of Indonesia's political dynamics. Religious issues play an important role in determining the vote when the election event arrives. Religion is a strategic issue for those concerned.

The emergence of the idea of forming the Baitul Muslimin Indonesia (BAMUSI) in the PDI Perjuangan body was a strategic step full of careful consideration which was rolled out by the PDI Perjuangan elite, considering that this party was a nationalist and religious party. 
This idea arises because religious (Islamic) stretches in PDI Perjuangan body increase and increase, especially after the emergence of stigmatization that PDI Perjuangan is an inherent party with abangan Islam. a new organization (BAMUSI) which is the right wing of PDI Perjuangan, whose Islamic nuances are undoubtedly to be formed and built.

BAMUSI is a new breakthrough for PDI Perjuangan to restore the negative stigmatization directed at PDI Perjuangan so far. BAMUSI is here to build a good image of PDI Perjuangan which has only been buzzing and narrating as a national and religious based party.

BAMUSI will make a movement towards Islamic understanding that is rahmatan lil 'alamin bagi for the nation. ${ }^{1}$ Understanding Islam as a religion full of the teachings of humanity and compassion for the common good as the nation's children who love their homeland.

The role of religion actually provides a space for liberation against a broad political space by keeping heed to the rules that have been set. Religion should be freed from the state, because when religion is used in government or in politics, religion will only become a political tool for those who have an interest. World affairs should be separated from spiritual matters so that religion occupies one of the most powerful thrones in its believing heart. ${ }^{2}$

Religion is no longer a sharp sword that is ready to overthrow its political opponents. But religion should be the locomotive of development in one frame, namely Bhineka Tunggal Ika. This is what happens in Indonesia. It is not excessive if religion is called an eternal phenomenon that is complex. It has been present since the beginning of human existence and has survived until today. That way as if religion does not recognize the changing times, because various social events experienced by humans do not eliminate their existence. Religion will always play a role in social, economic and political life. ${ }^{3}$

\section{Theoretical Review}

\subsection{Communication and the Scope of Communication}

Communication has a broader range of meanings than just what we have said so far. Communication is how we "say it". Communication can be defined as the exchange of ideas, communication is the information technician produced by sending stimulus from a source that the recipient responds to. ${ }^{4}$ The word or terms (from English "communication"), etymologically or according to the origin they are said to be from the Latin communicatus, and these words derive from the word communis, In the word communis it means 'sharing' or 'being shared' ie an effort which has a purpose for togetherness or similarity of meaning.

Communication in terminology refers to the process of delivering a statement by someone to someone else. So in this sense those involved in communication are human beings. The narcissus refers to the notion of Ruben and Steward (1998) regarding the communication between individuals: relationships, groups, organizations and community-responders to and create messages to adapt to the environment and one another. That human communication is a

\footnotetext{
${ }^{1}$ Interview with Hamka Haq, “BAMUSI Memperjuangkan Islam Yang Substansial” Majalah Bulanan Baitul Muslimin, (Keberagamaan, Kebangsaan \& Kebhinekaan, No. 02 August 2008). p.23

2 Soekarno, Di Bawah Bendera Revolusi (Jakarta: Panitia Penerbit Di Bawah Bendera

Revolusi, 1965), p. 404

${ }^{3}$ Bahtiar Effendy \& Hendro Prasetyo, ed., Radikalisme Agama (Jakarta: PPIM IAIN, 1998), p. vii

${ }^{4}$ Alo Liliweri, Komunikasi Serba Ada Serba Makna, (Jakarta: Kencana 2011), p. 35.
} 
process that involves individuals in a relationship, group, organization and community who creates messages to address the other environments. According to Wursanto communication is the process of conveying news information that means from one party (someone or place) to another party or person in an effort to obtain mutual understanding. In Kamus Besar Bahasa Indonesia, it is stated that communication is the sending or receiving of messages or news between two or more people in the right way so that the message in question can be understood; relationship; contact. ${ }^{5}$ Berlo in Erliana Hasan (2005) suggests communication as an atmosphere that is full of success if and only if the recipient of the message has meaning to the message where the meaning obtained is the same as what is intended by the source. ${ }^{6}$

Wibowo argues, communication is an activity to convey what is in mind, the concepts we have and the desires we want to convey to others. Or as an art of influencing other people to get what we want. Whereas Astrid argues that communication is the activity of passing symbols that contain meaning / meaning that needs to be understood together by parties seen in communication activities.

\subsection{Communication Strategy Theory}

From many communication theories put forward by experts, the basic theories related to communication strategies, as revealed by Melvin L. De Fleur quoted by Onong Uchjana Effendi in the book "Dimensions of Communication", there are four theories:

a. Individual Differences Theory, namely audiences as communicants selectively psychologically pay attention to a communication message if it relates to its interests, according to attitudes, beliefs and values.

b. Social Catagories Theory, that is even though modern society is haterogeneous but people who have the same nature will choose communication messages that are approximately the same and will give approximately the same response.

c. Social Relationship Theory, that is even though communication messages only arrive at someone but if someone is as an opinion leader, then the message content information as will be forwarded to other people also interpret it. It means that the opinion leader had a personal influence which is an important mechanism that can change communication messages.

d. Cultural Norms Theory, which is through selective presentation and emphasis on certain themes of mass media creates impressions on audiences that the same cultural norms about certain topics are formed in specific ways with the boundaries of individual situations, namely there are three :

- Reinforce existing patterns, that communication messages can strengthen existing patterns and direct people to believe that a social form is maintained by the community.

- Create a new shared convictions, that mass media can create new beliefs about a topic that on this topic is less experienced beforehand.

- Change existing norms, that mass media can change existing norms and therefore can change people's behavior

\footnotetext{
${ }^{5}$ Wursanto Ig Ilmu komunikasi teori dan praktek. (Yogyakarta: Kanisius, 2001), p. 31.

${ }^{6}$ Hasan, Erliana, Komunikasi Pemerintahan. (Bandung: PT. RafikaAditama, 2005), p.18.
} 


\subsection{Definition and Meaning of Imaging}

According to Soleh Soemirat and Elviriano, interpreting the image as an impression, feeling and image of the public towards the company or an impression that was deliberately created from an object, person or organization. ${ }^{7}$ Meanwhile, Ruslan stated that the image is something abstract or intangible, but its form can be felt from the results of assessment, acceptance, awareness, and understanding such as a sign of respect and respect, from the public or the wider community to the company or its trusted, professional, and reliable in providing good service. ${ }^{8}$

While Kotler explained the meaning of the image as a public perception of the company. People look for certain properties in the image. There must be a single message that shows the main advantages and position of the product. The message must also be unique so that it is not confused with similar messages from competitors. The message must also have emotional strength to generate feelings other than the buyer's mind. ${ }^{9}$

From the explanation above it can be understood that images can be formed entirely by how institutions are able to build perceptions based on the reality that occurs. All the processes that occur are certainly built with the credibility of the company, institution or organization. Imagery can also be understood as a construction of public representations and perceptions of individuals, groups or institutions related to their work in society.

While Kaid, states that, images in politics are created through the use of visual impressions communicated through appearances in the media, until information is integrated in the minds of the people. ${ }^{10}$ Thus, the thing that needs to be understood in connection with the formation of imagery is the perception that develops in the minds of the public towards the reality that appears in the media.

From this it is understood, imaging is very important for every organization, not least for political parties. Imaging for political parties is very influential in boosting vote acquisition in general elections. A positive image of a political party will be able to attract sympathetic mass supporters and the community. Therefore, this image is often one of the focuses of the attention of political communicators, both individually and in parties. This image is also often used by political parties to boost people's trust in their party.

According to the results of Fritz Plasser's research, it shows that the first factor that influences the chances of candidates to win elections in Europe is image or image. ${ }^{11}$ The image as the key to electoral victory has also become a necessity in Indonesia since the 2004 elections. The image is a human image of something, referring to Lippman, the image is the perception of something that is in someone's mind and that image is not always in accordance with actual reality. ${ }^{12}$

\footnotetext{
${ }^{7}$ Soleh Soemirat and Elviriano, Dasar-Dasar Publik Relations (Bandung: PT RemajaRosadakarya, 2002), pp. 111-112.

${ }^{8}$ Ruslan, Strategi Public Relations, Bauran Public Relations (Yogyakarta: Pustaka Pelajar, 1997), p. 50.

${ }^{9}$ Philip Kotler, Dasar-Dasar Pencitraan: Konsep dan Aplikasinya di Indonesia (Jakarta: Erlangga, 1994), p. 401.

${ }^{10}$ Lynda Lee Kaid, Handbook Penelitian Komunikasi Politik, Terj. Ahmad Asnawi (Bandung: Nusa Media, 2015), p. 26.

${ }^{11}$ Adam Nursal, Political Marketing: Strategi Memenangkan Pemilu (Jakarta: PT Gramedia Pustaka Utama, 2004), p. 75.

12 Jalaludin Rahmat, Psikologi Komunikasi (Bandung: Remaja Rosdakarya, 2001), p. 223.
} 
Political imagery is formed based on information received, both directly and through political media. Political imagery is one of the effects of political communication in a paradigm or mechanistic perspective, which is generally understood as an inherent impression in the minds of individuals or groups. Nevertheless the image can be different from the real reality or does not reflect the objective reality. The political image as explained by Arifin is related to the formation of public opinion, because basically political public opinion is built through political image.

\section{Research Method}

This study uses qualitative research because the focus of this research is on observation and natural atmosphere (naturalistic setting). ${ }^{13}$ This research attempts to understand the object being studied as it is, with natural analysis. ${ }^{14}$ According to Creswell quoted by Basuki, that qualitative research is a research process to understand human or social problems by creating a comprehensive and complex picture presented in words, reporting detailed views obtained from the sources of information, and done in settings (settings) natural. ${ }^{15}$

The approach which is used isa phenomenological approach, namely an approach that seeks to understand and explain phenomena that occur and appear on the surface. This research is to describe the reality that is happening without explaining the relationship between variables. ${ }^{16}$

Thus, this research aims to make a systematic, factual and accurate description of the facts of the object under study. That is, in this study, researchers tried to record, describe, describe and report on political imaging activities carried out by the Indonesian Baitul Muslimin in Medan in attracting public sympathy.

This research is conducted at the BAMUSI Medan City secretariat and the PDI Perjuangan Branch Manager in Medan City. This research is conducted for 8 months, starting from preliminary studies to guidance on completion of dissertations and open examinations. Regarding the time needed to complete this dissertation, according to the design, this study is completed within 8 months.

The data source of this study consists of two types, namely primary data and secondary data. Primary data is the main data that is used as the main material to be explored. The primary data sources in this study came from the management of BAMUSI Center, the Management of Bamusi Medan city, and the Executive Board of PDI Perjuangan Medan city.

The choice of Medan City because in this city PDI Perjuangan won at Peleg 2014 and succeeded in placing Kader as Chairman of the Deputy Mayor of Medan. Thus the Board of BAMUSI and the Leader of BAMUSI became the object of research as well as being key informants (key informants) who were expected to be able to provide the data needed in

\footnotetext{
${ }^{13}$ Jalaluddin Rakhmat, Metode Penelitian Komunikasi Dilengkapi Contoh Analisis Statistik (Bandung: Remaja Rosdakarya, 1984), p. 25.

${ }^{14}$ Deddy Mulyana, Metode Penelitian Kualitatif: Paradigma baru Ilmu Komunikasi dan Ilmu Sosial Lainnya (Bandung: Remaja Rosdakarya, 2004), pp. 157-159.

${ }^{15}$ Heru Basuki, Penelitian kualitatif: Untuk Ilmu-Ilmu Kemanusiaan dan Budaya (Jakarta: Universitas Gunadarma, 2006), p. 86.

${ }^{16}$ Rakhmat Kriyantono, Teknik Praktis Riset Komunikasi (Jakarta: Kencana, 2006), p. 69.
} 
accordance with the objectives of the study. In addition to the administrators from BAMUSI, informants were also taken from representatives of community leaders. ${ }^{17}$

\section{Discussion}

The concept of social service or social services is community service with a focus on personal, institutional and community. Personal means to involve medical personnel and services one by one. Institution means involving certain institutional organizations and networks. Society means society in general. Society is an important thing at community. The target of social service is how the people invited to think, behave and act to develop and develop themselves so that they care about their health. While BAMUSI Medan City especially the administrators who will be trained in the real life arena to become qualified cadres. For a party wing organization from PDI Perjuangan directly develops and applies community development theory. The targets for all of these lines involved all BAMUSI cadres and the party.

Who is involved in social work and community service, BAMUSI Medan City implements the application of work programs for organizations and parties to conduct community service with social services. In addition, it is expected to deal with multiple problems in a comprehensive (holistic) and sustainable manner. BAMUSI Medan City is increasingly active in the community in Medan City in building a positive image in increasing the electability of PDI Perjuangan. For BAMUSI, the city of Medan also serves as feedback from the community about the quality of its performance. In addition, it also strengthens cooperation for BAMUSI with involved networks such as the Medan City Government and other parties.

The community and community leaders were involved in every aspect of the socialization service carried out by BAMUSI Medan City all this time. The community can contribute energy assistance, thoughts, renewal, development cadres. The involvement of community leaders also respects their role. The involvement of community participation through PKK mothers and other women's groups (recitation, and others) is important because mothers are an important role in society. Cross-sectoral collaboration (local community health centers, medical teams and organizers) is something that should not be forgotten in the success of BAMUSI's social service activities.

One of the benefits of this activity is getting to know the community more closely and being able to capture the aspirations that grow in the community. Absorb their complaints and follow up through cooperation and maximum capacity owned by BAMUSI Medan City all this time. On the other hand the value of community service is the introduction of the culture of the community so that it will better appreciate the culture that comes from the grassroots in Medan City.

Social assistance is defined as the provision of assistance in the form of money / goods from institutions, organizations, individuals, groups to individuals, families, groups and / or communities that are not continuous and selective in order to protect against possible social risks. The social risk in question is an event that can create a potential for social vulnerability that is borne by individuals, families, groups and / or communities as a result of social crises,

\footnotetext{
${ }^{17}$ Burhan Bungin, Analisa Data Penelitian Kualitatif: Pemahaman Filosofis Ke Arah Penguasaan Model Aplikasi(Jakarta: PT Raja Grafindo Persada, 2003), p. 53.
} 
economic crises, political crises natural phenomena and natural disasters which if not given assistance funds social conditions will get worse and unable to live in fair conditions.

The provision of social assistance is adjusted to the financial capacity of an institution and is carried out selectively and after prioritizing the fulfillment of mandatory business expenses stipulated in the Regulations. The provision of social assistance is intended to support the achievement of program and activity targets, in this case BAMUSI Medan City by paying attention to the principles of justice, propriety, rationality and benefits for the community.

Social assistance carried out by BAMUSI Medan City to the members / community groups referred to as follows: Individuals, families and / or communities who experience unstable conditions as a result of social, economic, political, disaster or natural phenomena in order to fulfill their needs minimum, and non-governmental institutions in the fields of education, religion, and other fields whose role is to protect individuals, groups and communities from the possibility of social risks.

Social assistance is assistance that is non-binding and not mandatory and must be used in accordance with the approved proposal. Social assistance is temporary and not continuous, except in certain circumstances it can be sustainable. Social assistance as intended means that the provision of social assistance is not mandatory and does not have to be given every budget year. Social assistance in certain circumstances can be sustainable as intended to mean that social assistance spending can be given to maintain the level of social welfare or develop independence and to maintain the social performance that has been achieved so as not to decline again.

The provision of social assistance carried out by BAMUSI Medan City so far must meet the minimum criteria: selective, fulfill the requirements of beneficiaries, be temporary and not continuous, kecuai in certain circumstances can be sustainable; and according to the purpose of use. The distribution of aid by BAMUSI City of Medan is a routine activity and indeed has become a routine agenda in building a good image in the midst of the people of Medan.

Training is a learning process that involves acquiring skills, concepts, regulations, or attitudes to improve workforce performance. Training is intended to improve the mastery of various skills and techniques for implementing certain, detailed and routine work. That is the practice of preparing someone to do the work now. The training conducted by BAMUSI Medan City $\mathrm{n}$ is more focused on increasing the ability and expertise related to one's skills, so that it becomes a reference for skills in creating or preparing for employment. The target achieved and BAMUSI Medan City training program so far is to improve the performance or capability of the community in a particular field.

Capacity building carried out to the community tends to be more formal in nature, involving anticipation of individual abilities and expertise that must be prepared for the benefit of the economic needs of the community in the future. The targets and development programs involve a broader aspect, namely increasing the ability of individuals to anticipate changes that might occur unplened change or planed change. There have been several trainings conducted by BAMUSI Medan City all this time.

First: skill training is training that is often encountered in organizations. The training program is relatively simple: needs or vulnerabilities are identified through observant assessment. the criteria for evaluating the effectiveness of training are also based on the objectives identified in the assessment stage. Second: Retraining is a subset of skills training. Retraining seeks to provide communities with the skills they need to face the demands of changing work. Like the workforce of educational institutions that usually work using manual 
typewriters may have to be trained with computer machines or internet access. Third: Cross functional training (cross fungtional training) involves training the community to carry out work activities in other fields besides and work that has been practiced so far. Fourth: Team training is a partnership consisting of a group of individuals to complete work for the common goal in a work team. And fifth: creativity training (training creativity) based on the assumption that creativity can be learned. That is, labor is given the opportunity to issue ideas as freely as possible based on rational judgment.

The media now that we as creatures that live on this earth are no stranger to the existence of a media, a tool used to convey a message or information to a large audience for a particular purpose. The media itself is divided into several types, electronic media, print media, and new media. Electronic media itself includes radio, television. While print media includes tabloids, magazines, newspapers. For new media itself, it is like using the internet as a tool to find information that we are using up to now.

The use of media is very important, because to obtain an information we really need to use the media. Nowadays most people have switched to using new media as a tool to get information because of easy and fast access, but some of these people do not leave the main media used before, namely television, the main media used by some people today.

In a media, the image or good name of an individual or group can change according to certain goals. Image formation through media can be useful to improve the image of someone or a group from a bad image even if it is good and can also change a good image to be bad though, and also change the image of good to be better and worse to be worse. The process of changing the image of someone cannot just take place, it is necessary that the processes can change people's mindsets about it.

The media as a means of forming a positive image was carried out by BAMUSI Medan City in improving party image, namely PDI Perjuangan in the midst of the people of Medan. For BAMUSI Medan City, the media is very important because with a media that will capture the image / good name of the person. The use of media for BAMUSI itself is based on the interests of each individual and group in accordance with their respective interests, many at this time the parties that use broadcast media as a means of raising one's good name or image, of course they have a certain purpose.

In changing the image or good name of BAMUSI party not only using mass media, but they also often conduct socialization with the community. Forming an image does not only occur in a company or group, forming an image also occurs in BAMUSI Medan City for a particular purpose, this is very often the case and often encountered before the election, there are many candidates who try to promote themselves to change patterns think the community that he is a good leader, their goal is to motivate or give an encouragement to choose the candidate pair.

There are two sides to this, namely positive imaging, which aims to raise the electability of the political parties, the pairs of candidates and their supporting parties, as well as negative imagery to bring down their opponents. Like what happened at the five-yearly democratic party that took place from the Regency / City level to the Provision. Where each political party tries to present its best candidate pair to convince the public that they are the most suitable candidate to organize the city.

The above description is a form of the image of BAMUSI Medan City for the benefit of PDI Perjuangan Party. A media has a role to change the image of someone or party and institution whether it becomes better or worse. The media has taken a role in forming images 
for each individual and group. Media becomes a means to convey information about the image of each individual and group. At present the society is more consumptive about the news presented by the mass media in both written and television forms. Some people will trust the news and information conveyed by the information delivery media, therefore the image that will be formed from each individual or group is very dependent on the media.

\section{Conclusion}

Political imaging techniques carried out by BAMUSI in increasing the political support of the people of PDI Perjuangan Medan, namely to carry out social services: Social service activities carried out by BAMUSI Medan City is an accurate strategy in approaching and touching the hearts of Medan people in fostering community trust. Delivering Assistance: The political imaging technique carried out by BAMUSI Medan City in increasing community political support for PDI Perjuangan is by channeling aid. Making Training: BAMUSI Medan City imaging technique in improving PDI-P's political imagery is by making trainings in building community skills, training empowerment and community skills training. Using Media: For the development of social media and mass media as a tool to achieve the political image of PDI Perjuangan, BAMUSI Medan City always strives to increase political intimacy with the use of media

\section{Books:}

\section{References}

Ananda Santoso, Kamus Praktis Bahasa Indonesia, Surabaya: Dara Publik, 2001. Anwar Arifin, Politik Pencitraan - Pencitraan Politik, Yogyakarta: Graha Ilmu, 2014

Adam Nursal, Political Marketing: Strategi Memenangkan Pemilu, Jakarta: PT Gramedia Pustaka Utama, 2004.

Ardial, Komunikasi Politik, Jakarta: Indeks, 2010

Burgin, Burhan. Metode Penelitian Kualintatif. PT. Raja Grafindo Persada : Jakarta, 2002.

--------------, Analisa Data Penelitian Kualitatif: Pemahaman Filosofis Ke Arah Penguasaan Model Aplikasi, Jakarta: PT RajaGrafindo Persada, 2003

Bahtiar Effendy \& Hendro Prasetyo, ed., Radikalisme Agama, Jakarta: PPIM IAIN, 1998.

Brian McNair, An Introduction To Political Communication, London: Routledge, 2011.

Budiardjo, Miriam. Dasar-Dasar Ilmu Politik, Jakarta:Gramedia Pustaka Utama. 1995

Dan Nimmo, Komunikasi Politik; Khalayak dan Efek. Bandung: Remaja Rosdakarya, 2006

Departemen Pendidikan dan Kebudayaan RI, Kamus Besar Bahasa Indonesia, Jakarta: Balai Pustaka, 2005

Dedi Mulyana, Komunikasi Efektif: Suatu Pendekatan Lintas Budaya, Bandung: Remaja Rosdakarya, 2004. 2001 , Ilmu Komunikasi Suatu Pengantar, cet. 2, Bandung: PT Remaja Rosdakarya, , Metode Penelitian Kualitatif: Paradigma baru Ilmu Komunikasi dan Ilmu Sosial Lainnya, Bandung: Remaja Rosdakarya, 2004

Effendy, Onong, Uchjana. Televisi Siaran, Teori dan Praktek. Bandung : Alumni. 1984.

Everett M. Rogers dan F. Floyid Shoemaker, Communication of Innovations, terj. Abdillah Hanafi, Surabaya: Usaha Nasional, 1981 
Firmanzah, Marketing Politik: Antara Pemahaman dan Realitas, Jakarta: Yayasan Obor Indonesia, 2012

Goldhaber, Gerald M., Organizational Communication, Wm, C. Brown Publisher. 1990.

Gun Gun Heryanto, Komunikasi Politik, Jakarta: Universitas Indonesia 2010

Hamka Haq, "BAMUSI Memperjuangkan Islam Yang Substansial” Majalah Bulanan Baitul Muslimin, Keberagamaan, Kebangsaan \& Kebhinekaan, No. 02 Agustus 2008.

Hafied Cangara, Pengantar Ilmu Komunikasi, Jakarta: PT. RajaGrafindo Persada, 1998 , Komunikasi Politik: Konsep, Teori, dan Strategi, Jakarta: Rajawali Pers.

Heru Basuki, Penelitian kualitatif: Untuk Ilmu-Ilmu Kemanusiaan dan Budaya, Jakarta: Universitas Gunadarma, 2006

Ichlasul Amal, Teori Mutakhir Partai Politik, Yogyakarta: PT. Tiara Wacana, 1998

Jalaludin Rahmat, Psikologi Komunikasi, Bandung: Remaja Rosdakarya, 2001. Bandung: Remaja Rosdakarya, 1984

Lynda Lee Kaid, Handbook Penelitian Komunikasi Politik, Terj. Ahmad Asnawi, Bandung: Nusa Media, 2015

Littlejohn, Stephen W. 2009. Teori Komunikasi 9th Edition (Terjemahan). Jakarta : Penerbit Salemba Humanika.

Masmuh, Abdullah. Komunikasi Organisasi dalam Perspektif Teori dan Praktek. UMM Press. Malang.2008.

Maswardi Rauf dan Mappa Nasrun, Indonesia dan Komunikasi Politik, Jakarta: PT Gramedia Utama, 1993

Michael Rush dan Philip Althoff, Pengantar Sosiologi Politik, Jakarta: PT. RajaGrafindo Persada, 2004.

Matthew B. Miles dan A. Michael Huberman, Analisis Data Kualitatif, terj. Tjetjep Rohendi Rohidi, Jakarta: UI Press, 1992

Nimmo, Komunikasi Politik, Komunikator, Pesan dan Media, Bandung: PT. Remaja Rosdakarya, 2006

Onong Ucjhana Effendy, Ilmu Komunikasi Teori dan Praktek, Bandung: PT. Remaja Rosdakarya, 1984.

Pace, R. Wayne dan Don F. Faules, Komunikasi Organisasi, Bandung : Remaja Rosdakarya, 2002.

Peter Schroder, Strategi Politik, Jakarta: Friedrich Noumann Shiftung, 2004

Philip Kotler, Dasar-Dasar Pencitraan: Konsep dan Aplikasinya di Indonesia, Jakarta: Erlangga, 1994

Ruslan, Strategi Public Relations, Bauran Public Relations, Yogyakarta: Pustaka Pelajar, 1997

Rochajat Harun dan Sumarno AP, Komunikasi Politik, Bandung: Mandar Maju, 2006

Ramlan Surbakti, Memahami Ilmu Politik, Jakarta: PT. Grasindo, 2010

Rakhmat Kriyantono, Teknik Praktis Riset Komunikasi, Jakarta: Kencana, 2006

Soekarno, Di Bawah Bendera Revolusi, Jakarta: Panitia Penerbit Di Bawah Bendera Revolusi, 1965.

Soleh Soemirat dan Elviriano, Dasar-Dasar Publik Relations, Bandung: PT Remaja Rosadakarya, 2002

Silih Agung Wasesa, Political Branding \& Public Relation, Jakarta: Gramedia Pustaka Utama, 2011 
Silih Agung Wasesa dan J. Macnamara, Strategi Public Relations, Membangun Pencitraan Berbiaya Minimal dengan Hasil Maksimal, Jakarta: Gramedia Pustaka Utama, 2010.

Suyatno Kahar, "Pencitraan Politik Partai Nasdem Melalui Iklan di Televisi" dalam Jurnal Humanity, Vol. 9, No. 2, Maret 2014, Yogyakarta: UMM, 2014

Toni Andrianus Pito, dkk, Mengenal Teori-Teori Politik, Bandung: Penerbit Nuansa, 2009

\section{Print media:}

Mu'ti, Abdul, Seputar Indonesia, Opini : Baitul Muslimin dan Islam Kiri, edisi Kamis 9 Agustus, 2007

Fanani, Ahmad Fuad, Partai Islam Jelang Pemilu 2014, Opini Harian Seputar Indonesia, Edisi Kamis, 25 Oktober, 2012

Kompas, PDI-P gaet Syafi'i Ma'arif dan Said Aqil, edisi Senin, 6 Agustus, 2007.

Majalah Bulanan Baitul Muslimin, Penjaga gawang Nasionalisme : Wawancara Taufiq Kiemas, edisi Juli 2008.

Press Release, Deklarasi Baitul Muslimin Indonesia, DPP Bamusi, 27 Maret, 2007.

\section{Journals:}

Eka Cahyani dkk., Strategi Komunikasi Politik Partai Kebangkitan Bangsa dalam meningkatkan elektabilitas suara Partai di Kota Surabaya, Jurnal Administrasi Bisnis (JAB), Vol. 17 No. 2, Desember 2014.

Kuhlthau, Carol C, "Inside the Search Process: Information Seeking from the Users Perspective". Journal of the American Society for Information Science, Volume 42 No. 5: 1991.

Ruggiero, Thomas E. Uses and Gratification Theory in the $21^{s t}$ Century. Journal Mass Communication \& Society : University of Texas, 2000.

Soleh Rosyad dkk., Peningkatan Citra Partai dalam Kajian Komunikasi Politik menjelang Pemilu Tahun 2014, E-jurnal Management, Volume 1 Nomor 2, Tahun 2013.

DissertationAnang, Anas Azhar, Pencintraan Politik Partai Amanat Nasional (PAN) Dalam Menarik Simpati Masyarakat Di Provinsi Sumatera Utara Tahun 2005 - 2015( Disertasi UIN Sumatera Utara . 2016)

Erwan Efendi, Pengaruh Pencitraan Surat Kabar dan Religiusitas Terhadap Penentuan Pilihan Pemilih Dalam Pemilihan Kepala Daerah Sumatera Utara (Disertasi UIN Sumatera Utara: 2015).

\section{Informants}

Ahmad Basarah, Penasehat/ Pembina Pimpinan Pusat Baitul Muslimin Indonesia (BAMUSI), interview on January 29, 2019, at 1:00 p.m. until 14:30 p.m. in Jakarta.

Armen Daris Pasaribu, Ketua Baitul Muslimin Indonesia (BAMUSI) of North Sumatera, interview on January 28, 2019, at 10:00 a.m. to 12:30 p.m. WIB in Medan.

Hamka Haq, Ketua Umum Pimpinan Pusat Baitul Muslimin Indonesia (BAMUSI), interview on January 29, 2019. At 10:00 a.m. to 11:30 a.m. WIB in Jakarta.

Irmadi Lubis sebagai Dewan Pembina Baitul Muslimin Indonesia (BAMUSI) of North Sumatera and Medan City as well as Community Leaders in Medan City and North Sumatra, interview on January 27, 2019. At 10:00 a.m. to 11:30 a.m. WIB in Medan

Syahrul Efendi Siregar, Ketua Baitul Muslimin Indonesia (BAMUSI) of North Sumatera, interview on January 28, 2019, at 10:00 a.m. to 12:30 p.m. WIB in Medan 